\title{
TILLAGE IN RELATION TO DISTRIBUTION OF NUTRIENTS AND ORGANIC CARBON IN THE SOIL
}

\author{
BOŽENA ŠOLTYSOVÁ, MARTIN DANILOVIČ \\ Plant Production Research Center Piešt'any
}

ŠOLTYSOVÁ, B. - DANILOVIČ, M.: Tillage in relation to distribution of nutrients and organic carbon in the soil. Agriculture (Pol’nohospodárstvo), vol. 57, 2011, no. 1, pp. 21-30.

Changes of total nitrogen, available phosphorus, available potassium and soil organic carbon were observed on gleyic Fluvisols (locality Milhostov) at the following crops: grain maize (2005), spring barley (2006), winter wheat (2007), soya (2008), grain maize (2009). The experiment was realized at three soil tillage technologies: conventional tillage, reduced tillage and no-tillage. Soil samples were collected from three depths $(0-0.15 \mathrm{~m} ; 0.15-0.30 \mathrm{~m} ; 0.30-0.45 \mathrm{~m})$. The ratio of soil organic carbon to total nitrogen was also calculated.

Soil tillage affects significantly the content of total nitrogen in soil. The difference between the convetional tillage and soil protective tillages was significant. The balance showed that the content of total nitrogen decreased at reduced tillage by 5.2 rel.\%, at no-tillage by 5.1 rel.\% and at conventional tillage by 0.7 rel. $\%$.
Similarly, the content of organic matter in the soil was significantly affected by soil tillage. The content of soil organic carbon found at the end of the research period was lower by 4.1 rel.\% at reduced tillage, by 4.8 rel.\% at no-tillage and by 4.9 rel. $\%$ at conventional tillage compared with initial stage. The difference between the convetional tillage and soil protective tillages was significant.

Less significant relationship was found between the soil tillage and the content of available phosphorus. The balance showed that the content of available phosphorus was increased at reduced tillage (by $4.1 \mathrm{rel} . \%$ ) and was decreased at no-tillage (by 9.5 rel.\%) and at conventional tillage (by 3.3 rel.\%).

Tillage did not significantly affect the content of available potassium in the soil.

Key words: gleyic Fluvisols, soil tillage system, soil depth, total nitrogen, phosphorus, potassium, soil organic carbon

Soil tillage is one of the important factors influencing the changes in soil chemical properties. It is necessary to test the tillage technologies in specific soil conditions and subsequently to use the technologies that support conservation of soil fertility. Monitoring of soil properties variation is crucial, especially for long-term use of no-tillage (Šabatková et al. 2006).

Soil organic matter is considered to be a key indicator during the valuation of soil quality (Barančíková 2006). Soil moisture and air regime change, as a result of different tillage, and this affects the intensity of decomposition and transformation of soil organic matter. The soil organic matter decomposition rate is reduced when there is no ploughing. Organic matter accumulates in the surface layer and subsequently the content of total carbon in- creases (Olson et al. 2005; Šmanský et al. 2007; Lehocká et al. 2008; Yaduvanshi \& Sharma 2008; Domínquez et al. 2009).

Tillage affects the content and distribution of nutrients and organic matter in soil. The increase of total nitrogen content in the surface layers of soil was found at no-tillage compared with conventional tillage (López-Fando et al. 2007; Roldán et al. 2007; Dou et al. 2008; Jokela et al. 2009; López-Fando \& Pardo 2009). The increase of phosphorus and potassium was also found by Guzman et al. (2006), Omonode et al. (2006), Rueda et al. (2007), Dong et al. (2009) and Šoltysová and Danilovič (2009). Organic carbon may be also increased as a result of higher input of organic carbon into the top layers (Malo et al. 2005; Badalíko-

Ing. Božena Šoltysová, PhD., Ing. Martin Danilovič, PhD., Plant Production Research Center Piešt’any - Research Institute of Agroecology Michalovce, 07101 Michalovce, Špitálska 1273. E-mail: soltysova@minet.sk 
vá 2006; Dou et al. 2008).

Besides the above mentioned quantity, the quality of soil organic matter is important as well. The ratio of organic carbon to the total nitrogen content in soil is calculated for the quality assurance. The more intensive the decomposition of organic matter, the lower the $\mathrm{C}: \mathrm{N}$ ratio (Tobiašová 2006).

The aim of this study was to evaluate the changes of selected soil chemical parameters in soil profile of gleyic Fluvisols affected by different soil tillage.

\section{MATERIAL AND METHODS}

The field experiment was initiated in 2005 at the experimental station of the Agroecology Research Institute, which is located in Milhostov $\left(48^{\circ} 40^{\prime} \mathrm{N}, 21^{\circ} 43^{\prime} \mathrm{E}\right)$. The experimental station is situated in the central part of the East-Slovak Lowland at an altitude of $101 \mathrm{~m}$. Average annual temperature is $8.9^{\circ} \mathrm{C}\left(16.0^{\circ} \mathrm{C}\right.$ during vegetation period) and average annual rainfall is $560 \mathrm{~mm}(350 \mathrm{~mm}$ during vegetation period). The soil is gleyic Fluvisols. According to Novak classificatory scale (Zaujec et al. 2009), this soil subtype belongs to heavy and clayeyloamy soils (average content of clay particles is $47.8 \%$ ). More detailed description of the site can be found in the study by Sútor et al. (2002).

The average values of chemical properties of the topsoil (depth from 0 to $0.3 \mathrm{~m}$ ) measured in 2005 are available phosphorus content $51 \mathrm{mg} \mathrm{kg}^{-1}$ (Mehlich III), available potassium content $242 \mathrm{mg} \mathrm{kg}^{-1}$ (Mehlich III), available magnesium content $460 \mathrm{mg} \mathrm{kg}^{-1}$ (Mehlich III),

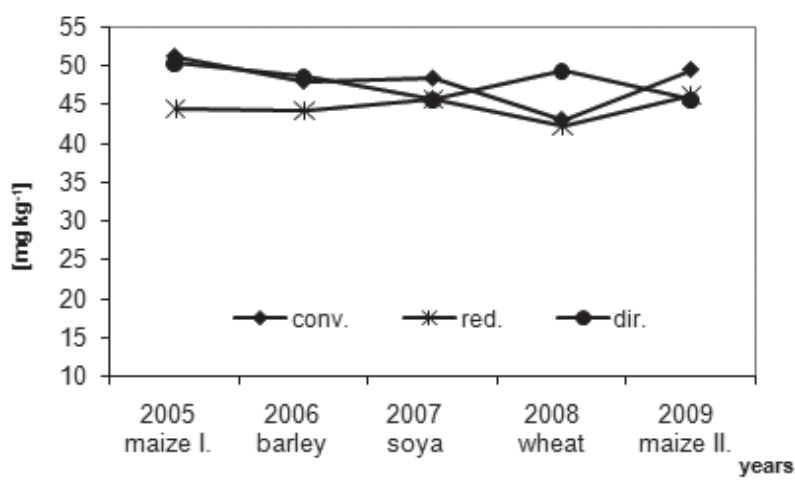

Fig. 1. Content of available phosphorus in depth $0-0.45 \mathrm{~m}$

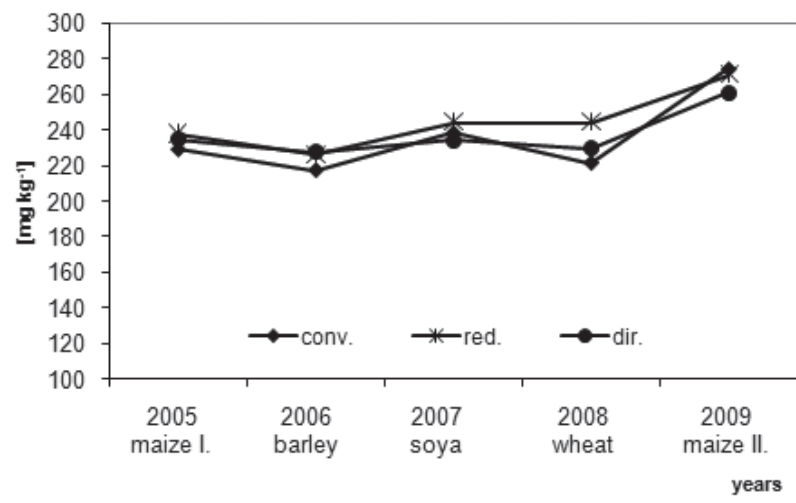

Fig. 2. Content of avaiable potassium in the depth $0-0.45 \mathrm{~m}$

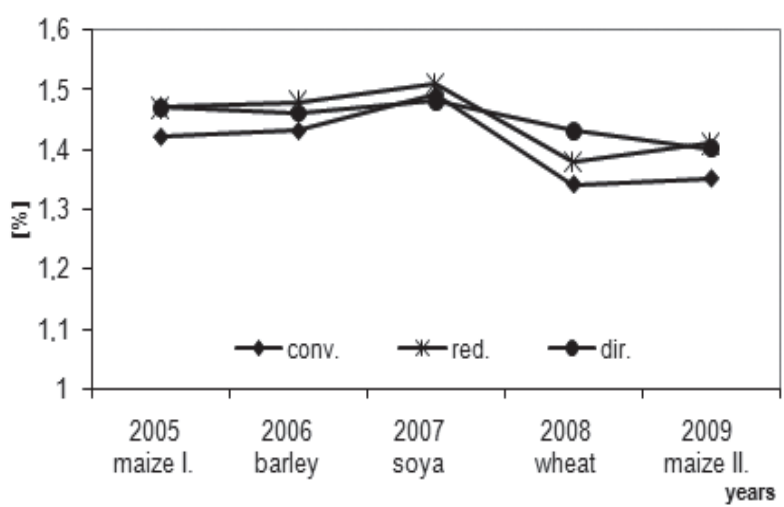

Fig. 4. Content of total nitrogen in the depth $0-0.45 \mathrm{~m}$

Fig. 3. Content of total nitrogen in the depth $0-0.45 \mathrm{~m}$ 
exchangeable calcium content $5200 \mathrm{mg} \mathrm{kg}^{-1}$ (Mehlich III), soil reaction $(\mathrm{KCl}) 6.3$, humus content $2.9 \%$, the type of humus is from humate-fulvic to fulvic-humate with humic acids and fulvic acids ratio from 0.8 to 1.2 .
The experiment field was planted with grain maize I. (Zea mays L.) in the year 2005, spring barley (Hordeum vulgare L.) in the year 2006, soya (Glycine $\max$ (L.) Merr.) in the year 2007, winter wheat (Triticum aestivum

$\mathrm{T}$ a b 1 e 1

The doses of pure nutrients used for fertilization

\begin{tabular}{|c|c|c|c|}
\hline Crop & $\begin{array}{c}\mathrm{N} \\
{\left[\mathrm{kg} \mathrm{ha}^{-1}\right]}\end{array}$ & $\begin{array}{c}\mathrm{P} \\
{\left[\mathrm{kg} \mathrm{ha}^{-1}\right]}\end{array}$ & $\begin{array}{c}\mathrm{K} \\
{\left[\mathrm{kg} \mathrm{ha}^{-1}\right]}\end{array}$ \\
\hline Grain maize & 90 & 30 & 90 \\
\hline Spring barley & 30 & 24 & 90 \\
\hline Soya & 50 & 45 & 80 \\
\hline Winter wheat & 150 & 35 & 140 \\
\hline
\end{tabular}

T a b 1 e 2

The content of available phosphorus and potassium in the soil

\begin{tabular}{|c|c|c|c|c|c|c|c|c|c|}
\hline \multirow{2}{*}{$\begin{array}{c}\text { Parameter } \\
\text { of soil }\end{array}$} & \multirow{2}{*}{ Tillage } & \multirow{2}{*}{$\begin{array}{l}\text { Soil depth } \\
{[\mathrm{m}]}\end{array}$} & \multicolumn{5}{|c|}{ Experimental years } & \multirow{2}{*}{$\bar{x} Y$} & \multirow{2}{*}{$\begin{array}{c}\text { Rel. \% } \\
2009: \\
2005\end{array}$} \\
\hline & & & 2005 & 2006 & 2007 & 2008 & 2009 & & \\
\hline \multirow{9}{*}{$\begin{array}{c}\mathrm{P} \\
{\left[\mathrm{mg} \mathrm{kg}^{-1}\right]}\end{array}$} & \multirow{3}{*}{ conv. } & $0.00-0.15$ & 53.4 & 54.5 & 51.9 & 54.3 & 59.1 & 54.6 & 110.7 \\
\hline & & $0.15-0.30$ & 52.9 & 51.5 & 46.4 & 46.8 & 48.9 & 49.3 & 92.4 \\
\hline & & $0.30-0.45$ & 47.1 & 37.7 & 46.5 & 28.0 & 40.2 & 39.9 & 85.4 \\
\hline & \multirow{3}{*}{ red. } & $0.00-0.15$ & 50.2 & 51.9 & 53.3 & 53.0 & 61.6 & 54.0 & 122.7 \\
\hline & & $0.15-0.30$ & 45.5 & 46.8 & 43.6 & 44.4 & 39.5 & 44.0 & 86.8 \\
\hline & & $0.30-0.45$ & 37.4 & 33.5 & 40.4 & 29.0 & 37.2 & 35.5 & 99.5 \\
\hline & \multirow{3}{*}{ dir. } & $0.00-0.15$ & 52.7 & 54.9 & 55.8 & 61.1 & 54.8 & 55.8 & 104.0 \\
\hline & & $0.15-0.30$ & 51.6 & 49.3 & 47.8 & 51.4 & 42.1 & 48.4 & 81.6 \\
\hline & & $0.30-0.45$ & 46.7 & 41.5 & 32.9 & 35.2 & 39.5 & 39.2 & 84.6 \\
\hline \multirow{9}{*}{$\begin{array}{c}\mathrm{K} \\
{\left[\mathrm{mg} \mathrm{kg}^{-1}\right]}\end{array}$} & \multirow{3}{*}{ conv. } & $0.00-0.15$ & 246.2 & 238.0 & 247.9 & 236.6 & 302.9 & 254.3 & 123.0 \\
\hline & & $0.15-0.30$ & 226.0 & 219.2 & 239.2 & 223.3 & 277.4 & 237.0 & 122.7 \\
\hline & & $0.30-0.45$ & 215.3 & 195.4 & 228.4 & 204.9 & 242.9 & 217.4 & 112.8 \\
\hline & \multirow{3}{*}{ red. } & $0.00-0.15$ & 260.0 & 250.5 & 257.1 & 277.4 & 324.4 & 273.9 & 124.8 \\
\hline & & $0.15-0.30$ & 233.2 & 221.3 & 248.1 & 225.5 & 262.2 & 238.1 & 112.4 \\
\hline & & $0.30-0.45$ & 220.5 & 206.4 & 227.7 & 229.5 & 226.4 & 222.1 & 102.7 \\
\hline & \multirow{3}{*}{ dir. } & $0.00-0.15$ & 255.3 & 254.3 & 267.6 & 260.2 & 289.4 & 265.4 & 113.4 \\
\hline & & $0.15-0.30$ & 228.3 & 230.1 & 232.1 & 228.1 & 259.7 & 235.6 & 113.8 \\
\hline & & $0.30-0.45$ & 220.7 & 198.9 & 203.4 & 201.5 & 234.0 & 211.7 & 106.0 \\
\hline
\end{tabular}

$\overline{\mathrm{X}} \mathrm{Y}$ - average for experimental years

$\mathrm{P}$ - available phosphorus

$\mathrm{K}$ - available potassium conv. - conventional tillage

red. - reduced tillage

dir. - no-tillage 
L.) in the year 2008, and with the grain maize II. in the year 2009. The doses of pure nutrients used for fertilization are presented in the Table 1.

The trial was established with three types of tillage:

- conventional tillage - depending on the growing crop, a stubble breaking and stubble or deep ploughing was done; pre-sowing soil treatment was done using a cul- tivator and sowing was done by the sowing machine Kinze 2000 (maize) or Great Plains (wheat, barley, soya),

- reduced tillage - shallow soil cultivation was done using stubble plough after forecrop harvesting, presowing soil treatment was done using cultivator and sowing was done by the sowing machine Kinze 2000

$\mathrm{T}$ a

The content of total nitrogen, soil organic carbon and ratio of soil organic carbon to total nitrogen

\begin{tabular}{|c|c|c|c|c|c|c|c|c|c|}
\hline \multirow{2}{*}{$\begin{array}{c}\text { Parameter } \\
\text { of soil }\end{array}$} & \multirow{2}{*}{ Tillage } & \multirow{2}{*}{ Soil depth $[\mathrm{m}]$} & \multicolumn{5}{|c|}{ Experimental years } & \multirow{2}{*}{$\overline{\mathrm{x}} \mathrm{Y}$} & \multirow{2}{*}{$\begin{array}{c}\text { Rel.\% } \\
2009: 2005\end{array}$} \\
\hline & & & 2005 & 2006 & 2007 & 2008 & 2009 & & \\
\hline \multirow{9}{*}{$\begin{array}{l}\mathrm{N}_{\mathrm{t}} \\
{[\%]}\end{array}$} & \multirow{3}{*}{ conv. } & $0.00-0.15$ & 0.151 & 0.147 & 0.167 & 0.156 & 0.146 & 0.153 & 96.7 \\
\hline & & $0.15-0.30$ & 0.147 & 0.136 & 0.163 & 0.145 & 0.147 & 0.147 & 100.0 \\
\hline & & $0.30-0.45$ & 0.142 & 0.127 & 0.160 & 0.130 & 0.143 & 0.141 & 100.7 \\
\hline & \multirow{3}{*}{ red. } & $0.00-0.15$ & 0.160 & 0.151 & 0.171 & 0.163 & 0.154 & 0.160 & 96.3 \\
\hline & & $0.15-0.30$ & 0.157 & 0.146 & 0.163 & 0.151 & 0.147 & 0.153 & 93.6 \\
\hline & & $0.30-0.45$ & 0.149 & 0.141 & 0.155 & 0.130 & 0.141 & 0.143 & 94.6 \\
\hline & \multirow{3}{*}{ dir. } & $0.00-0.15$ & 0.160 & 0.157 & 0.173 & 0.172 & 0.149 & 0.162 & 93.1 \\
\hline & & $0.15-0.30$ & 0.156 & 0.144 & 0.164 & 0.162 & 0.150 & 0.155 & 96.2 \\
\hline & & $0.30-0.45$ & 0.154 & 0.141 & 0.149 & 0.142 & 0.148 & 0.147 & 96.1 \\
\hline \multirow{9}{*}{$\begin{array}{l}\mathrm{C}_{\text {ox. }} \\
{[\%]}\end{array}$} & \multirow{3}{*}{ conv. } & $0.00-0.15$ & 1.49 & 1.47 & 1.52 & 1.49 & 1.36 & 1.47 & 91.3 \\
\hline & & $0.15-0.30$ & 1.46 & 1.46 & 1.49 & 1.39 & 1.37 & 1.43 & 93.8 \\
\hline & & $0.30-0.45$ & 1.32 & 1.36 & 1.46 & 1.15 & 1.33 & 1.32 & 100.8 \\
\hline & \multirow{3}{*}{ red. } & $0.00-0.15$ & 1.56 & 1.53 & 1.58 & 1.56 & 1.49 & 1.54 & 95.5 \\
\hline & & $0.15-0.30$ & 1.51 & 1.49 & 1.49 & 1.34 & 1.40 & 1.44 & 92.7 \\
\hline & & $0.30-0.45$ & 1.35 & 1.43 & 1.45 & 1.25 & 1.33 & 1.36 & 98.5 \\
\hline & \multirow{3}{*}{ dir. } & $0.00-0.15$ & 1.56 & 1.53 & 1.64 & 1.58 & 1.42 & 1.54 & 91.0 \\
\hline & & $0.15-0.30$ & 1.50 & 1.48 & 1.46 & 1.39 & 1.42 & 1.45 & 94.7 \\
\hline & & $0.30-0.45$ & 1.34 & 1.39 & 1.33 & 1.33 & 1.35 & 1.35 & 100.7 \\
\hline \multirow{9}{*}{$\mathrm{C}_{\mathrm{ox} .} / \mathrm{N}_{\mathrm{t}}$} & \multirow{3}{*}{ conv. } & $0.00-0.15$ & 9.89 & 10.01 & 9.17 & 9.50 & 9.44 & 9.60 & 95.4 \\
\hline & & $0.15-0.30$ & 9.96 & 10.75 & 9.15 & 9.61 & 9.32 & 9.76 & 93.6 \\
\hline & & $0.30-0.45$ & 9.28 & 10.69 & 9.12 & 8.79 & 9.29 & 9.43 & 100.1 \\
\hline & \multirow{3}{*}{ red. } & $0.00-0.15$ & 9.76 & 10.17 & 9.30 & 9.61 & 9.70 & 9.71 & 99.4 \\
\hline & & $0.15-0.30$ & 9.62 & 10.19 & 9.14 & 8.91 & 9.50 & 9.47 & 98.8 \\
\hline & & $0.30-0.45$ & 9.12 & 10.27 & 9.31 & 9.64 & 9.45 & 9.56 & 103.6 \\
\hline & \multirow{3}{*}{ dir. } & $0.00-0.15$ & 9.71 & 9.73 & 9.53 & 9.16 & 9.57 & 9.54 & 98.6 \\
\hline & & $0.15-0.30$ & 9.63 & 10.27 & 8.90 & 8.57 & 9.48 & 9.37 & 98.4 \\
\hline & & $0.30-0.45$ & 8.71 & 9.91 & 8.93 & 9.38 & 9.20 & 9.23 & 105.6 \\
\hline \multicolumn{10}{|c|}{$\begin{array}{l}\overline{\mathrm{X}} \mathrm{Y}-\text { average for experimental years } \\
\mathrm{N}_{\mathrm{t}}-\text { total nitrogen } \\
\mathrm{C}_{\text {ox. }}-\text { soil organic carbon }\end{array}$} \\
\hline
\end{tabular}


(maize) or Great Plains (wheat, barley, soya),

barley, soya).

- no-tillage - direct sowing was done by the sowing The size of all variant surfaces was $414 \mathrm{~m}^{2}$ machine Kinze 2000 (maize) or Great Plains (wheat, $\quad(18 \times 23 \mathrm{~m})$ and the randomized block design and four

$\mathrm{T}$ a b 1 e 4

Analysis of variance of observed soil parameters

\begin{tabular}{|c|c|c|c|c|}
\hline Soil parameter & Source of variation & d.f. & F-ratio & $\mathrm{P}$ \\
\hline $\mathrm{P}$ & $\begin{array}{l}\text { depth } \\
\text { tillage } \\
\text { crop } \\
\text { repetition } \\
\text { residual } \\
\text { total }\end{array}$ & $\begin{array}{r}2 \\
2 \\
4 \\
3 \\
168 \\
179\end{array}$ & $\begin{array}{r}55.18 \\
3.07 \\
0.88 \\
0.86\end{array}$ & $\begin{array}{l}++ \\
+ \\
- \\
-\end{array}$ \\
\hline K & $\begin{array}{l}\text { depth } \\
\text { tillage } \\
\text { crop } \\
\text { repetition } \\
\text { residual } \\
\text { total }\end{array}$ & $\begin{array}{r}2 \\
2 \\
4 \\
3 \\
168 \\
179\end{array}$ & $\begin{array}{r}68.25 \\
2.48 \\
21.53 \\
2.05\end{array}$ & $\begin{array}{l}++ \\
- \\
++ \\
-\end{array}$ \\
\hline $\mathrm{N}_{\mathrm{t}}$ & $\begin{array}{l}\text { depth } \\
\text { tillage } \\
\text { crop } \\
\text { repetition } \\
\text { residual } \\
\text { total }\end{array}$ & $\begin{array}{r}2 \\
2 \\
4 \\
3 \\
168 \\
179\end{array}$ & $\begin{array}{r}39.93 \\
10.66 \\
23.19 \\
1.40\end{array}$ & $\begin{array}{l}++ \\
++ \\
++ \\
-\end{array}$ \\
\hline $\mathrm{C}_{\text {ox. }}$ & $\begin{array}{l}\text { depth } \\
\text { tillage } \\
\text { crop } \\
\text { repetition } \\
\text { residual } \\
\text { total }\end{array}$ & $\begin{array}{r}2 \\
2 \\
4 \\
3 \\
168 \\
179\end{array}$ & $\begin{array}{r}71.02 \\
5.64 \\
12.34 \\
2.05\end{array}$ & $\begin{array}{l}++ \\
++ \\
++ \\
-\end{array}$ \\
\hline $\mathrm{C}_{\mathrm{ox}} / \mathrm{N}_{\mathrm{t}}$ & $\begin{array}{l}\text { depth } \\
\text { tillage } \\
\text { crop } \\
\text { repetition } \\
\text { residual } \\
\text { total }\end{array}$ & $\begin{array}{r}2 \\
2 \\
4 \\
3 \\
168 \\
179\end{array}$ & $\begin{array}{r}1.60 \\
2.10 \\
14.92 \\
1.44\end{array}$ & $\begin{array}{l}- \\
- \\
++ \\
-\end{array}$ \\
\hline
\end{tabular}

${ }^{+} \mathrm{P}<0.05 \quad{ }^{++} \mathrm{P}<0.01$

d.f. - degrees of freedom

F-ratio - calculated F-ratio

$\mathrm{P}-$ effect of a factor significant at the level $\alpha=0.05$

or $\alpha=0.01$

$\mathrm{P}$ - available phosphorus
$\mathrm{K}$ - available potassium

$\mathrm{N}_{\mathrm{t}}$ - total nitrogen

$\mathrm{C}_{\text {ox. }}$ - soil organic carbon

$\mathrm{C}_{\mathrm{ox}} / \mathrm{N}_{\mathrm{t}}$ - ratio of soil organic carbon to total nitrogen 
replications were used for this experiment. Soil samples were collected from three depths of $0-0.15 \mathrm{~m}$ (1 $1 \mathrm{st})$, $0.15-0.30 \mathrm{~m}$ (2nd) and $0.30-0.45 \mathrm{~m}$ ( $3 \mathrm{rd})$, annually in the autumn. The disturbed soil samples were analysed using well-known methodologies to determine the following chemical soil parameters: total nitrogen was determined by Kjeldahl method (Hraško 1962), available phosphorus and potassium by Mehlich III method

$\mathrm{T}$ a b 1 e 5

Multiplied test comparing the observed parameters of soil $\left(\operatorname{LSD}_{0.05}\right)$

\begin{tabular}{|c|c|c|c|c|c|c|c|c|c|c|c|}
\hline Soil parameter & \multicolumn{2}{|c|}{ Observed factor } & \multicolumn{3}{|c|}{ Homogenous group } & \multicolumn{2}{|c|}{ Observed factor } & \multicolumn{4}{|c|}{ Homogenous group } \\
\hline \multirow{5}{*}{$P$} & \multirow{3}{*}{ depth } & $0.30-0.45$ & $\mathrm{x}$ & & & \multirow{4}{*}{ crop } & wheat & $\mathrm{x}$ & & & \\
\hline & & $0.15-0.30$ & & $\mathrm{x}$ & & & soya & $\mathrm{x}$ & & & \\
\hline & & $0.00-0.15$ & & & $\mathrm{x}$ & & barley & $\mathrm{x}$ & & & \\
\hline & \multirow[t]{2}{*}{ tillage } & $\begin{array}{l}\text { red. } \\
\text { dir. }\end{array}$ & $\mathrm{x}$ & \multirow{2}{*}{$\begin{array}{l}x \\
x\end{array}$} & & & $\begin{array}{l}\text { maize II. } \\
\text { maize I. }\end{array}$ & $\begin{array}{l}x \\
x\end{array}$ & & & \\
\hline & & conv. & & & & & & & & & \\
\hline \multirow{6}{*}{$\mathrm{K}$} & & $0.30-0.45$ & $\mathrm{x}$ & & & \multirow{5}{*}{ crop } & barley & $\mathrm{x}$ & & & \\
\hline & depth & $0.15-0.30$ & & $\mathrm{x}$ & & & wheat & $\mathrm{x}$ & $\mathrm{x}$ & & \\
\hline & & $0.00-0.15$ & & & $\mathrm{x}$ & & maize I. & $\mathrm{x}$ & $\mathrm{x}$ & & \\
\hline & \multirow{3}{*}{ tillage } & conv. & $\mathrm{x}$ & \multirow{3}{*}{$\begin{array}{l}x \\
x\end{array}$} & & & soya & & $\mathrm{x}$ & & \\
\hline & & dir. & $\mathrm{x}$ & & & & maize II. & & & $\mathrm{x}$ & \\
\hline & & red. & & & & & & & & & \\
\hline \multirow{5}{*}{$\mathrm{N}_{\mathrm{t}}$} & & $0.30-0.45$ & $\mathrm{x}$ & & & \multirow{4}{*}{ crop } & barley & $\mathrm{x}$ & & & \\
\hline & depth & $0.15-0.30$ & & $\mathrm{x}$ & & & maize II. & $\mathrm{x}$ & $\mathrm{x}$ & & \\
\hline & & $0.00-0.15$ & & & $\mathrm{x}$ & & wheat & & $\mathrm{x}$ & $\mathrm{x}$ & \\
\hline & \multirow[t]{2}{*}{ tillage } & $\begin{array}{l}\text { conv. } \\
\text { red. }\end{array}$ & $\mathrm{x}$ & \multirow{2}{*}{$\begin{array}{l}x \\
x\end{array}$} & & & $\begin{array}{c}\text { maize I. } \\
\text { soya }\end{array}$ & & & $\mathrm{x}$ & $\mathrm{x}$ \\
\hline & & dir. & & & & & & & & & \\
\hline \multirow{6}{*}{$\mathrm{C}_{\text {ox. }}$} & & $0.30-0.45$ & $\mathrm{x}$ & & & \multirow{5}{*}{ crop } & maize II. & $\mathrm{x}$ & & & \\
\hline & depth & $0.15-0.30$ & & $\mathrm{x}$ & & & wheat & $\mathrm{x}$ & & & \\
\hline & & $0.00-0.15$ & & & $\mathrm{x}$ & & maize I. & & $\mathrm{x}$ & & \\
\hline & \multirow{3}{*}{ tillage } & conv. & $\mathrm{x}$ & \multirow{3}{*}{$\begin{array}{l}x \\
x\end{array}$} & & & barley & & $\mathrm{x}$ & & \\
\hline & & dir. & & & & & soya & & $\mathrm{x}$ & & \\
\hline & & red. & & & & & & & & & \\
\hline \multirow{5}{*}{$\mathrm{C}_{\mathrm{ox}} / \mathrm{N}_{\mathrm{t}}$} & & $0.30-0.45$ & $\mathrm{x}$ & & & \multirow{5}{*}{ crop } & soya & $\mathrm{x}$ & & & \\
\hline & depth & $0.15-0.30$ & $\mathrm{x}$ & & & & wheat & $\mathrm{x}$ & $\mathrm{x}$ & & \\
\hline & & $0.00-0.15$ & $\mathrm{x}$ & & & & maize II. & $\mathrm{x}$ & $\mathrm{x}$ & & \\
\hline & \multirow[b]{2}{*}{ tillage } & dir. & $\mathrm{x}$ & & & & maize I. & & $\mathrm{x}$ & & \\
\hline & & $\min$. & $\mathrm{x}$ & & & & barley & & & $\mathrm{x}$ & \\
\hline
\end{tabular}

$\alpha=0.05-$ limit significant difference at the level $\alpha=0.05$

$$
\left(\mathrm{LSD}_{0.05}\right)
$$

conv. - conventional tillage, red. - reduced tillage,

dir. - no-tillage

$\mathrm{P}$ - available phosphorus

$\mathrm{K}$ - available potassium

$\mathrm{N}_{\mathrm{t}}$ - total nitrogen
$\mathrm{C}$ - soil organic carbon

$\mathrm{C}_{\mathrm{ox}} / \mathrm{N}_{\mathrm{t}}$ - ratio of soil organic carbon to total nitrogen

maize I. - grain maize (year 2005)

barley - spring barley (year 2006)

soya - soya (year 2007)

wheat - winter wheat (year 2008)

maize II. - grain maize (year 2009) 
T a b 1 e 6

Yield of field crops $\left[\mathrm{tha}^{-1}\right]$

\begin{tabular}{|l|c|c|c|c|}
\hline \multirow{2}{*}{ Tillage } & 2006 & 2007 & 2008 & 2009 \\
\cline { 2 - 5 } & spring barley & soya & winter wheat & grain maize \\
\hline Conventional & 2.72 & 2.18 & 6.65 & 11.88 \\
Reduced & 2.48 & 1.86 & 6.26 & 10.62 \\
No-tillage & 2.18 & 1.82 & 5.60 & 9.88 \\
\hline
\end{tabular}

(Trávník et al. 1999) and organic carbon by Tyurin method (Hraško 1962). The ratio of organic carbon to total nitrogen was determined by calculation.

Multi-factorial analysis of variance (ANOVA) was used to evaluate the treatment effects on the distribution of nutrients and organic carbon in soil. Differences between treatments means were assessed by the least significant difference (LSD) test. All statistical analyses were performed using the Statgraphics software package.

\section{RESULTS AND DISCUSSION}

Contents of available phosphorus, available potassium, total nitrogen and organic soil carbon in observed tillages and soil depths are shown in Table 2 and 3. In the total soil depth $(0-0.45 \mathrm{~m})$, the mean content of available phosphorus was in the range from 42.1 $\mathrm{mg} \mathrm{kg}^{-1}$ to $51.1 \mathrm{mg} \mathrm{kg}^{-1}$, content of available potassium was from $217.5 \mathrm{mg} \mathrm{kg}^{-1}$ to $274.4 \mathrm{mg} \mathrm{kg}^{-1}$, the total nitrogen content was from $0.137 \%$ to $0.163 \%$ and the content of soil organic carbon was from $1.34 \%$ to $1.51 \%$ (Fig. 1-4). Significant effect of soil depth on the content of selected soil parameters was observed (Table 4). The highest content of the abovementioned parameters was detected in the top depth of soil $(0-0.15 \mathrm{~m})$ and the lowest in the lowest depth $(0.30 \mathrm{~m}$ to $0.45 \mathrm{~m})$. The difference between the first and the third soil depth was in available phosphorus $16.6 \mathrm{mg} \mathrm{kg}^{-1}$, in available potassium $47.5 \mathrm{mg} \mathrm{kg}^{-1}$, in total nitrogen content $0.015 \%$ and in soil organic carbon $0.18 \%$. Lower levels of total nitrogen were found in deeper soil depths by Jokela et al. (2009) and López-Fando and Pardo (2009) and of available phosphorus and potassium by Omonode et al. (2006) and Dong et al. (2009). The decline of soil organic carbon with soil depth was recorded also by Malo et al. (2005), Šabatková et al. (2006), Dong et al.
(2009) and others.

The balance showed (Table 3), that the content of total nitrogen decreased at reduced tillage by $5.2 \mathrm{rel} . \%$, at no-tillage by $5.1 \mathrm{rel} . \%$ and at conventional tillage by 0.7 rel.\%. Higher content of total nitrogen in conventional technology was probably caused by higher crop yields (Table 6) and crop residues. Higher yields were recorded at conventional tillage compared with no-tillage by Danilovič and Šoltysová (2007), Lehocká et al. (2008) and Hnát (2009).

Soil tillage also affects the intensity of decomposition of soil organic matter. Higher mean contents of soil organic carbon (in depth $0-0.45 \mathrm{~m}$ ) were found at soil protective tillages (1.45\%) compared with conventional tillage $(1.41 \%)$. The greatest difference was found in the top depth $(0-0.15 \mathrm{~m})$. The content of soil organic carbon in the mentioned soil depth was $1.54 \%$ at protective tillages and $1.47 \%$ at conventional tillage. Higher content of soil organic matter at no-tillage compared with conventional tillage was also found by Roldán et al. (2007), Dou et al. (2008), Yaduvanshi and Sharma (2008) and Domínquez et al. (2009). The content of soil organic carbon found at the end of research period was lower by $4.1-4.9$ rel.\% compared with initial stage at all variants of tillage.

Less significant relationship was found between the soil tillage and the content of available phosphorus (Table 4). The balance showed that the content of available phosphorus was increased at reduced tillage (by 4.1 rel.\%) and was decreased at no-tillage (by 9.5 rel.\%) and conventional tillage (by 3.3 rel.\%).

Significant relationship was found at available potassium, total nitrogen and soil organic carbon in relation to the cultivated crop (Table 4). The lowest content of available potassium and total nitrogen was found after barley cultivation. The highest content of total nitrogen was found after soya cultivation and the 
highest content of available potassium after maize cultivation (Table 5). The effect of a crop is influenced by the genetic material and by the intesity of cultivation in relation to productivity (nutrition, tillage ...). Phosphorus and potassium fertilisation of barley, wheat and soya we can designate as intesive, because the doses were higher than needed for the achieved biological yield. We found a decline in the content of phosphorus despite of intensive fertilisation. The lowest content of phosphorus was found after wheat cultivation. In the case of potassium it was found, that its content in soil was increasing throughout the experiment. The cumulative effect of higher rates of nutrients was demonstrated after maize cultivation (the last cultivated crop) which was fertilized insufficiently. The content of available potassium in the soil after the maize cultivation was significantly higher than in the beginning of the experiment. The content of phosphorus did not change substantially. Annual changes of soil chemical properties, although without relation to cultivated crops, were also found by Novotná and Lošák (2007).

The intensity of cultivation in relation to productivity was also demonstrated at soil organic carbon and total nitrogen. Crops remains (roots, postharvest and straw) were the sole source of organic matter. Achieved yields of barley and soya did not balance out annual losses of soil organic carbon. Soil organic carbon was subsequently decreased. Significant relationship was also found between the crop and total nitrogen in soil. Annual changes of soil organic carbon and total nitrogen, although without relation to cultivated crops, were also found by Barančíková (2004).

The calculated ratio of organic carbon to total nitrogen

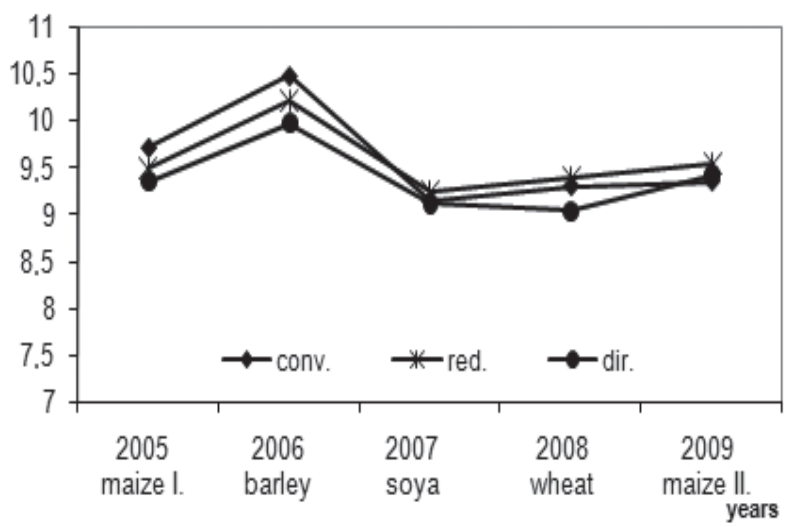

Fig. 5. The ratio of soil organic carbon to total nitrogen content in the depth $0-0.45 \mathrm{~m}$ is the indicator of humus quality, e.g. it indicates organic matter fortification by proteins (Sotáková 1982). The ratio $\mathrm{C}_{\mathrm{ox}}: \mathrm{N}_{\mathrm{t}}$ was from 9.04 to 10.48 at observed variants of tillage in total depth $0-0.45 \mathrm{~m}$ (Fig. 5). Soil organic matter decomposition was intensive according to the calculated ratio, but the relationship between the ratio and tillage and between the ratio and soil depth was not significant. Significant relationship was found only between the ratio and crops (Table 5).

\section{CONCLUSION}

From the results obtained between 2005 and 2009 about the effect of different soil tillage on selected soil chemical parameters, it is possible to formulate conclusions as follows:

Soil tillage affects significantly the content of total nitrogen in soil. The balance showed that the content of total nitrogen decreased at reduced tillage by 5.2 rel.\%, at no-tillage by 5.1 rel.\% and at conventional tillage by 0.7 rel.\%. The difference between the convetional tillage and soil protective tillages was significant.

Soil tillage also significantly affects the content of organic matter in the soil. The difference between the convetional tillage and soil protective tillages was significant. Content of soil organic carbon found at the end of research period was lower by $4.1 \mathrm{rel} . \%$ at reduced tillage, by 4.8 rel. $\%$ at no-tillage and by 4.9 rel. $\%$ at conventional tillage compared with initial stage.

It was found that the influence of soil tillage on the content of available phosphorus was less significant. The balance showed, that the content of available phosphorus was increased at reduced tillage (by $4.1 \mathrm{rel} . \%$ ) and was decreased at no-tillage (by 9.5 rel.\%) and conventional tillage (by 3.3 rel.\%). Tillage did not significantly affect the content of available potassium in soil.

Relationship between the content of soil chemical parameters and soil depths was significant. The highest content of observed parameters was detected in the top depth of soil $(0-0.15 \mathrm{~m})$ and the lowest in the lowest depth ( $0.30 \mathrm{~m}$ to $0.45 \mathrm{~m})$.

Acknowledgement. This research was supported by the Ministry of Agriculture of Slovak Republic. 


\section{REFERENCES}

BADALÍKOVÁ, B. 2006. Změny obsahu humusu a jeho kvality při různém zpracování půdy $\mathrm{k}$ cukrovce [The changes of humus content and his qualities with different soil tillage by sugar beet]. In ŠARAPATKA, B. - BEDNÁŘ, M. (Eds.): Pedogenesis and soil quality changes in terms of natural and anthropic affected erea: proceeding from $11^{\text {th }}$ pedological days. Kouty the Desna : Palacký University Olomouc, Czech Society of Soil Science, 2006. ISBN 80244-1448-1, pp. 251-256.

BARANČÍKOVÁ, G. 2004. Soil organic matter and humic acids chemical structure of calcaric and non-calcaric mollic fluvisol. In Agriculture (Pol'nohospodárstvo), vol. 50, 2004, no. 7-9, pp. 124-131.

BARANČÍKOVÁ, G. 2006. Pôdna organická hmota ako základný indikátor pri hodnotení vybraných ekologických funkcií pôdy [Soil organic matter - basic indicator at soil ecological functions assessment]. In Agrochémia, vol. 46, 2006, no. 3, pp. 19-23.

DANILOVIČ, M. - ŠOLTYSOVÁ, B. 2007. Obrábanie pôdy vo vzt'ahu $\mathrm{k}$ úrode a kvalite zrna jačmeňa siateho jarného [Soil cultivation and its effect on grain yield and grain quality parameters in spring barley]. In Agriculture (Polnohospodárstvo), vol. 53, 2007, no. 2, pp. 102-108.

DOMÍNQUEZ, G.F. - DIOVISALVI, N.V. - STUDDERT, G.A. - MONTERUBBIANESI, M.G. 2009. Soil organic C and $\mathrm{N}$ fractions under continuous cropping with contrasting tillage systems on mollisols of the southeastern Pampas. In Soil and Tillage Research, vol. 102, 2009, no. 1, pp. 93-100.

DONG, X.W. - ZHANG, X.K. - BAO, X.L. - WANG, J.K. 2009. Spatial distribution of soil nutrients after the establishment of sand-fixing shrubs on sand dune. In Plant Soil Environment, vol. 55, 2009, no. 7, pp. 288-294.

DOU, F. - WRIGHT, A.L. - HONS, F.M. 2008. Dissolved and soil organic carbon after long-term conventional and no-tillage sorghum cropping. In Communications in soil science and plant analysis, vol. 39, 2008, no. 5-6, pp. 667-679.

GUZMAN, J.G. - GODSEY, CH.B. - PIERZYNSKI, G.M. WHITNEY, D.A. - LAMOND, R.E. 2006. Effect of tillage and nitrogen management on soil chemical and physical properties after 23 years of continuous sorghum. In Soil and Tillage Research, vol. 91, 2006, no. 1-2, pp. 199-206.

HNÁT, A. 2009. The dependence of grain yield (Zea Mays L.) from different soil tillage and meteorological conditions. In Agriculture (Pol'nohospodárstvo), vol. 55, 2009, no. 3, pp. $148-155$.

HRAŠKO, J. et al. 1962. Rozbory pôd [Soil analyses]. Bratislava : Slovak Publish. Pedol. Lit., 1962. 342 pp.

JOKELA, W.E. - GRABBER, J.H. - KARLEN, D.L. BALSER, T.C. - PALMQUIST, D.E. 2009. Cover Crop and Liquid Manure Effects on Soil Quality Indicators in a Corn Silage System. In American Society of Agronomy, vol. 101, 2009, no. 4, pp. 727-737.

LEHOCKÁ, Z. - KLIMEKOVÁ, M. - BIELIKOVÁ, M. - ŽÁK, Š. 2008. Crop yield and response of soil quality indicators to no tillage practice in a loam degraded chernozem on loess in Slovakia. In Ecomit : $5^{\text {th }}$ International Scientific Conference on Sustainable Farming Systems. Pieštany :
Slovak Agricultural Research Centre - Research Institute of Plant Production, 2008. ISBN 978-80.969603-1-6, pp. 50-54.

LÓPEZ-FANDO, C. - DORADO, J. - PARDO, M.T. 2007.

Effects of zone-tillage in rotation with no-tillage on soil properties and crop yields in a semi-arid soil from central Spain. In Soil and Tillage Research, vol. 95, 2007, no. 1-2, pp. 266-276.

LÓPEZ-FANDO, C. - PARDO, M.T. 2009. Changes in soil chemical characteristics with different tillage practice in semi-arid environment. In Soil and Tillage Research, vol. 104, 2009, no. 2, pp. 278-284.

MALO, D.D. - SCHUMACHER, T.E. - DOOLITTLE, J.J. 2005. Long-term cultivation impacts on selected soil properties in the northern Great Plains. In Soil and Tillage Research, vol. 81, 2005, no. 2, pp. 277-291.

NOVOTNÁ, J. - LOŠÁK, T. 2007. Changes in agrochemical properties of discharge soil of the daz waste dump: " $z$ at the gasworks". In Ecological Chemistry and Engineering, vol. 14, 2007, no. 3-4, pp. 357-362.

OLSON, K.R. - LANG, J.M. - EBELHAR, S.A. 2005. Soil organic carbon changes after 12 years of no-tillage and tillage of Grantsburg soils in southern Illinois. In Soil and Tillage Research, vol. 81, 2005, no. 2, pp. 217-225.

OMONODE, R.A. - GAL, A. - STOTT, D.E. - ABNEY T.S. - VYN, T.J. 2006. Short-term Versus Continuous Chisel an No-till Effects on Soil Carbon and Nitrogen. In Soil Science Society of America Journal, vol. 70, 2006, no. 2, pp. 419-425.

ROLDÁN, A. - SALINAS-GARCÍA, J.R. - ALGUACIL, M. M. - CARAVACA, F. 2007. Soil sustainability indicators following conservation tillage practices under subtropical maize and bean crops. In Soil and Tillage Research, vol. 93, 2007, no. 2, pp. 273-282.

RUEDA, I.M. - GUERRA, L.M.M - YUNTA, F. - ESTEBAN, E. - TENORIO, J.L. - LUCENA, J.J. 2007. Tillage and crop rotation effects on barley yield and soil nutrients on a Calciortidic Haploxeralf. In Soil and Tillage Research, vol. 92, 2007, no. 1-2, pp. 1-9.

SOTÁKOVÁ, S. 1982. Organická hmota a úrodnost' pôdy [Organic matter and soil fertility]. Bratislava : Nature, 1982, $234 \mathrm{pp}$.

ŠABATKOVÁ, O. - HORÁČEK, J. - LIEBHARD, P. KOPEČNÁ, J. - ČECHOVÁ, V. 2006. Vliv minimalizačních technologií na kvantitativní parametry půdní organické hmoty kambizemě a černozemě [Minimum tillage effect on soil organic matter quantitative parameters of cambisol and chernozem]. In ŠARAPATKA, B. - BEDNÁR̆, M. (Eds.): Pedogenesis and soil quality changes in terms of natural and anthropic affected erea: proceeding from $11^{\text {th }}$ pedological days. Kouty the Desna : Palacký University Olomouc, Czech Society of Soil Science, 2006. ISBN 80244-1448-1, pp. 349-354.

ŠIMANSKÝ, V. - TOBIAŠOVÁ, E. - ZAUJEC, A. 2007. Vplyv obrábania na stabilitu pôdnej štruktúry vo vzt’ahu ku kvantite a kvalite pôdnej organickej hmoty [Influence of tillage on soil structure stability with regard to quantity and quality of soil organic matter]. In Agrochémia, vol. 47, 2007, no. 1, pp. 27-30.

ŠOLTYSOVÁ, B. - DANILOVIČ, M. 2009. Vertikálna variabilita chemických parametrov pôdy [The vertical variabili- 
ty of soil chemical parameters]. In Transport of Water, Chemicals and Energy in the System Soil - Crop Canopy - Atmosphere : $17^{\text {th }}$ International Poster days. Bratislava : Institute of Hydrology SAS, 2009. ISBN 978-80-8913919-4, pp. 617-623.

ŠÚTOR, J. - GOMBOŠ, M. - MATI, R. et al. 2002. Charakteristiky zóny aerácie tažkých pôd Východoslovenskej nižiny [The characteristics of aeration zone of heavy soil of the East Slovak Lowland]. Bratislava : Institute of Hydrology SAS, Michalovce : Research Institute of Agroecology, 2002. 215 pp. ISBN 80-968480-8-9.

TOBIAŠOVÁ, E. 2006. Kvantita a kvalita pôdnej organickej hmoty $v$ rôznych systémoch pestovania plodín [Quantity and quality of soil organic matter in different crop farming systems]. In ŠARAPATKA, B. - BEDNÁŘ, M. (Eds.): Pedogenesis and soil quality changes in terms of natural and anthropic affected erea: proceeding from $11^{\text {th }}$ pedological days. Kouty the Desna : Palacký University Olomouc,
Czech Society of Soil Science, 2006. ISBN 80-244-14481, pp. 359-363.

TRÁVNÍK, V. - ZBÍRAL, J - NĚMEC, P. 1999. Agrochemické zkoušeni zemédělských půd - Metoda Mehlich III [Agrochemical testing of agricultural soils - Method Mehlich III]. Brno : Central Institute for Supervising and Testing in Agriculture, 1999. pp. 58-82.

YADUVANSHI, N.P.S. - SHARMA, D.R. 2008. Tillage and residual organic manures/chemical amendment effects on soil organic matter and yield of wheat under sodic water irrigation. In Soil and Tillage Research, vol. 98, 2008, no. 1, pp. 11-16.

ZAUJEC, A. et al. 2009. Pedológia a základy geológie [Pedology and basis of geology]. Nitra : SUA, 2009. 399 pp. ISBN 978-80-552-0207-5

Received: August, 2th, 2010 